\title{
Risk factors and outcomes of ventilator-associated pneumonia in COVID-19 patients: a propensity score matched analysis
}

\author{
María Martínez-Martínez ${ }^{1}$, Erika P. Plata-Menchaca ${ }^{1}$, Francesc X. Nuvials', Oriol Roca ${ }^{1,2}$ and Ricard Ferrer $^{1,2^{*}}$ (D)
}

\section{Dear Editor}

Mechanically ventilated patients with coronavirus disease (COVID-19) may be at an increased risk of developing ventilator-associated pneumonia (VAP). Our aim was to describe the clinical characteristics, risk factors, and outcomes associated with VAP in critically ill COVID-19 patients.

In this single-center cohort study, all adult patients with laboratory-confirmed COVID-19, based on the detection of viral sequences by real-time reverse-transcription polymerase chain reaction, who needed mechanical ventilation (MV) between March 1, and April 30, 2020 were included. The local ethics committee approved this study and waived the need for informed consent due to the observational nature of the study. VAP was defined according to the current American Thoracic Society/ Infectious Diseases Society of America guidelines criteria [1]. Differences between quantitative variables were assessed by Student $t$-test or Mann-Whitney $U$-test. Chi-square or Fisher's exact tests were used to analyze categorical data. To determine which variables were independently associated with VAP, a logistic regression analysis was performed, including the variables with $p<0.1$ in the univariate analysis. To assess the influence of VAP in outcomes and account for inter-group imbalances of baseline characteristics, we conducted a propensity

\footnotetext{
*Correspondence: r.ferrer@vhebron.net

${ }^{1}$ Servei de Medicina Intensiva, Hospital Universitari Vall d'Hebron,

Institut de Recerca Vall d'Hebron, Passeig de la Vall d'Hebron, 119-129, 08035 Barcelona, Spain

Full list of author information is available at the end of the article
}

score matching including those variables with $p<0.1$ in the univariate analysis. In all cases, 1:1 matching without replacement was used with a caliper 0.2 standard deviation of logit of the propensity score and with the nearest neighbor method. In the matched cohorts, differences in the categorical variables were analyzed using McNemar's test, and differences in continuous variables were determined using paired t-test or Wilcoxon signed-rank test, as appropriate. All statistical analyses were performed using the Stata Statistical Software 14 (StataCorp 15. College Station, TX: StataCorp LP) and R, version 3.6.3 (R project for Statistical Computing, http://www.R-project. org).

Of the 353 patients admitted to the intensive care unit (ICU) during the study period, 250 (70.8\%) required invasive MV (Table 1). VAP occurred in 100 (40\%) of the mechanically ventilated patients. Of these, 78 were confirmed by a positive quantitative culture and 22 were defined by clinical criteria and a purulent respiratory sample. Median time to the diagnosis of VAP was 13 (8-20) days, with only 11 developing VAP within the first $96 \mathrm{~h}$ of admission. Antibiotic treatment was adequate in $89 \%$ of the cases. Admission to an open ICU (contingency unit without physical barriers between patients) (odds ratio [OR], 1.85; 95\% confidence interval [CI], [1.04-3.33]; $p=0.037)$, higher Sequential Organ Failure Assessment score (OR 1.55; 95\% CI [1.21-2.00]; $p=0.001$ ), corticosteroid treatment (OR 3.26; 95\% CI [1.78-5.97]; $p<0.001)$ and treatment with tocilizumab (OR 1.85; 95\% CI [1.02-3.38]; $p=0.044$ ) before VAP were independently associated with VAP development. After propensity score matching, VAP was associated with original author(s) and the source, provide a link to the Creative Commons licence, and indicate if changes were made. The images or other third party material in this article are included in the article's Creative Commons licence, unless indicated otherwise in a credit line to the material. If material is not included in the article's Creative Commons licence and your intended use is not permitted by statutory regulation or exceeds the permitted use, you will need to obtain permission directly from the copyright holder. To view a copy of this licence, visit http://creativecommons.org/licenses/by/4.0/. The Creative Commons Public Domain Dedication waiver (http://creativeco mmons.org/publicdomain/zero/1.0/) applies to the data made available in this article, unless otherwise stated in a credit line to the data. 
Table 1 Clinical characteristics of the unmatched cohort

\begin{tabular}{|c|c|c|c|c|}
\hline & All $(n=250)$ & No VAP $(n=150)$ & $\operatorname{VAP}(n=100)$ & $p$-value \\
\hline Age, median (IQR) & $59(51-67)$ & $57(51-67)$ & $61.5(52.5-67)$ & 0.216 \\
\hline Gender (male), $n(\%)$ & $173(69.2 \%)$ & $97(64.7 \%)$ & $76(76 \%)$ & 0.057 \\
\hline $\mathrm{BMI}>30$, median (IQR) & $101(40.4 \%)$ & $63(42 \%)$ & $38(38 \%)$ & 0.528 \\
\hline Admission to an open ICU unit, $n(\%)$ & $136(54.2 \%)$ & $74(49.7 \%)$ & $61(61 \%)$ & 0.078 \\
\hline $\begin{array}{l}\text { Length of MV before onset of VAP vs. non VAP (days), } \\
\text { median (IQR) }\end{array}$ & $13(8-20)$ & $12(8-19)$ & $14(9-21.5)$ & 0.202 \\
\hline \multicolumn{5}{|l|}{ Severity and comorbidity scores } \\
\hline APACHE II, median (IQR) & $11(8-13)$ & $10(7-13)$ & $12(9-14)$ & 0.055 \\
\hline SOFA, median (IQR) & $4(3-5)$ & $4(3-5)$ & $5(3-6)$ & $<0.001$ \\
\hline Charlson Comorbidity Index, median (IQR) & $2(1-3)$ & $2(1-3)$ & $2(1-3)$ & 0.888 \\
\hline \multicolumn{5}{|l|}{ COVID-19 related therapies } \\
\hline Use of prior antibiotics, $n(\%)$ & $250(100 \%)$ & $150(100 \%)$ & $100(100 \%)$ & 1 \\
\hline Corticosteroids, $n(\%)^{*}$ & 75 (30\%) & $30(20 \%)$ & $45(45 \%)$ & $<0.001$ \\
\hline Tocilizumab, $n(\%)^{* *}$ & $153(60.8 \%)$ & $80(53.3 \%)$ & $72(72 \%)$ & 0.003 \\
\hline Lopinavir-ritonavir, n (\%) & $184(73.6 \%)$ & $110(73.3 \%)$ & $74(74 \%)$ & 0.907 \\
\hline Remdesivir, $n(\%)$ & $9(3.6 \%)$ & $136(90.7 \%)$ & $96(96 \%)$ & 0.110 \\
\hline Hydroxychloroquine, $n$ (\%) & $232(92.8 \%)$ & $4(2.7 \%)$ & $5(5 \%)$ & 0.332 \\
\hline \multicolumn{5}{|l|}{ Other ICU therapies } \\
\hline Anticoagulation, $n(\%)$ & $86(34.4 \%)$ & $46(30.7 \%)$ & $40(40 \%)$ & 0.128 \\
\hline ECMO, $n(\%)$ & $21(8.4 \%)$ & $11(7.3 \%)$ & $10(10 \%)$ & 0.456 \\
\hline CRRT, $n(\%)$ & $12(4.8 \%)$ & $7(4.7 \%)$ & $5(5.1 \%)$ & 0.890 \\
\hline \multicolumn{5}{|l|}{ Outcomes } \\
\hline Length of MV (days), median (IQR) & $17(10-26)$ & $12(8-20)$ & $25(20-34)$ & $<0.001$ \\
\hline Length of ICU stay (days), median (IQR) & $18(12-26)$ & $12(8-20)$ & $25(20-34)$ & $<0.001$ \\
\hline ICU mortality, n (\%) & $59(23 \%)$ & $24(16 \%)$ & $35(35 \%)$ & $<0.001$ \\
\hline
\end{tabular}

APACHE II, Acute Physiologic Assessment and Chronic Health Evaluation II Score; BMI, Body Mass Index; COVID-19, coronavirus disease; CRRT, continuous renal replacement therapy; ECMO, Extracorporeal membrane oxygenation; ICU, Intensive Care Unit; IQR, interquartile range; MV, Mechanical ventilation; SOFA, Sequential Organ Failure Assessment Score; VAP, Ventilator-associated pneumonia

*Median time between corticosteroid initiation and the diagnosis of VAP was 10 days IQR (7-14)

**Tocilizumab was administered prior to ICU admission

Table 2 Differences in variables included in propensity score in the matched cohort

\begin{tabular}{|c|c|c|c|c|}
\hline & No VAP $(n=78)$ & $\operatorname{VAP}(n=78)$ & $\begin{array}{l}\text { Difference between means } \\
(95 \% \mathrm{Cl})\end{array}$ & $p$-value \\
\hline Gender (male), n (\%) & $56(71.8)$ & $60(76.9)$ & $5.1(-8.5$ to 18.8$)$ & 0.463 \\
\hline Admission to an open ICU unit, $n(\%)$ & $46(59)$ & $47(60.3)$ & $1.3(-14.1$ to 16.7$)$ & 0.87 \\
\hline APACHE II, median (IQR) & $10(7-13)$ & $11.5(9-14)$ & $-0.5(-2$ to 1$)$ & 0.758 \\
\hline SOFA, median (IQR) & $4(3-5)$ & $4(3-5)$ & $-0.1(-0.7$ to 0.5$)$ & 0.759 \\
\hline Corticosteroids, $n$ (\%) & $28(35.9 \%)$ & $32(41 \%)$ & $5.1(-10.1$ to 20.4$)$ & 0.51 \\
\hline Tocilizumab, $n(\%)$ & $55(70.5 \%)$ & $53(68 \%)$ & $-2.6(-17$ to 11.9$)$ & 0.729 \\
\hline Length of MV (days), median (IQR) & $12(8-20)$ & $24(17-33)$ & $-11.2(-17.1$ to -5.3$)$ & $<0.001$ \\
\hline Length of ICU stay, median (IQR) & $15(9-23)$ & $25(20-34)$ & $-11.6(-17.9$ to -5.3$)$ & $<0.001$ \\
\hline ICU Mortality, n (\%) & $11(14.1 \%)$ & $25(32.1 \%)$ & $-17.9(-30.9$ to -5.0$)$ & $<0.01$ \\
\hline
\end{tabular}

APACHE II, Acute Physiologic Assessment and Chronic Health Evaluation II Score; Cl, confidence interval; ICU, intensive care unit; IQR, interquartile range; MV, Mechanical ventilation; SOFA, Sequential Organ Failure Assessment Score; VAP, Ventilator-associated pneumonia 
a longer duration of MV and ICU stay and higher ICU mortality (Table 2).

According to the results reported, VAP is a frequent complication among mechanically ventilated COVID-19 patients $[2,3]$ and strongly impacts outcomes. It has been reported that COVID-19 makes patients more prone to VAP, not entirely due to the increased duration of the MV [3]. Despite the 28-day mortality benefit observed with corticosteroid use $[4,5]$ and controversies regarding tocilizumab use [6], both treatments were initiated prior to VAP occurrence, and often prior to ICU admission, and are independently associated with a higher risk of VAP. Limitations of the present study include its observational nature, single-center setting, and the fact that the total dose of administered steroids was not recorded. However, our findings suggest that excessive immunosuppression associated with the use of immunomodulatory drugs may facilitate VAP development in COVID-19 patients.

\section{Abbreviations}

COVID-19: Coronavirus disease 2019; Cl: Confidence interval; ICU: Intensive care unit; MV: Mechanical ventilation; OR: Odds ratio; VAP: Ventilator-associated pneumonia.

\section{Acknowledgements}

Not applicable.

\section{Authors' contributions}

MMM was responsible for the acquisition of the data and the initial draft. EPM, FXN, OR, and RF contributed substantially to the study design, data analysis, interpretation and the writing of the manuscript. All authors approved the final version to be published and agree to be accountable for all aspects of the work in ensuring that questions related to the accuracy or integrity of any part of the work are appropriately investigated and resolved. All authors read and approved the final manuscript.

\section{Funding}

No funding.

\section{Availability of data and materials}

The datasets used and analysed during the current study are available from the corresponding author on reasonable request.

\section{Declarations}

Ethics approval and consent to participate

The local ethics committee (CEIm [Comitè d'Ėtica d'Investigació amb medicaments], Vall d'Hebron Institut de Recerca, Barcelona, Spain) approved this study and waived the need for informed consent due to the observational nature of the study.

\section{Consent for publication}

Not applicable.

\section{Competing interests}

MMM declares that she has no competing interests. EPM declares that she has no competing interests. FXNC has received speaker fees from MSD, Pfizer, Shionogi, and Gilead outside the submitted work. OR has received research grants and speaker fees from Hamilton Medical outside the submitted work. RF has received speaker fees from MSD, Pfizer, Shionogi, and Gilead outside the submitted work.

\section{Author details}

${ }^{1}$ Servei de Medicina Intensiva, Hospital Universitari Vall d'Hebron, Institut de Recerca Vall d'Hebron, Passeig de la Vall d'Hebron, 119-129, 08035 Barcelona, Spain. ${ }^{2}$ Centro de Investigación Biomédica en Red de Enfermedades Respiratorias (CIBER), Madrid, Spain.

Received: 16 April 2021 Accepted: 23 June 2021

Published online: 06 July 2021

\section{References}

1. Kalil AC, Metersky ML, Klompas M, Muscedere J, Sweeney DA, Palmer LB, Napolitano LM, O'Grady NP, Bartlett JG, Carratalà J, et al. Management of adults with hospital-acquired and ventilator-associated pneumonia: 2016 clinical practice guidelines by the Infectious Diseases Society of America and the American Thoracic Society. Clin Infect Dis. 2016;63(5):e61-111.

2. Clinical characteristics and day-90 outcomes of 4244 critically ill adults with COVID-19: a prospective cohort study. Intensive Care Med. 2020;1-14.

3. Maes M, Higginson E, Pereira-Dias J, Curran MD, Parmar S, Khokhar F, Cuchet-Lourenço D, Lux J, Sharma-Hajela S, Ravenhill B, et al. Ventilatorassociated pneumonia in critically ill patients with COVID-19. Crit Care. 2021;25(1):25.

4. RECOVERY Collaborative Group, Horby P, Lim WS, Emberson JR, Mafham M, Bell JL, Linsell L, Staplin N, Brightling C, Ustianowski A, Elmahi E, Prudon B, Green C, Felton T, Chadwick D, Rege K, Fegan C, Chappell LC, Faust SN, Jaki T, Jeffery K, Montgomery A, Rowan K, Juszczak E, Baillie JK, Haynes $\mathrm{R}$, Landray MJ. Dexamethasone in hospitalized patients with Covid-19. N Engl J Med. 2021;384(8):693-704.

5. Sterne JAC, Murthy S, Diaz JV, Slutsky AS, Villar J, Angus DC, Annane D, Azevedo LCP, Berwanger O, Cavalcanti AB, et al. Association between administration of systemic corticosteroids and mortality among critically III patients with COVID-19: a meta-analysis. JAMA. 2020;324(13):1330-41.

6. Stone JH, Frigault MJ, Serling-Boyd NJ, Fernandes AD, Harvey L, Foulkes AS, Horick NK, Healy BC, Shah R, Bensaci AM, Woolley AE, Nikiforow S, Lin N, Sagar M, Schrager H, Huckins DS, Axelrod M, Pincus MD, Fleisher J, Sacks CA, Dougan M, North CM, Halvorsen YD, Thurber TK, Dagher Z, Scherer A, Wallwork RS, Kim AY, Schoenfeld S, Sen P, Neilan TG, Perugino CA, Unizony SH, Collier DS, Matza MA, Yinh JM, Bowman KA, Meyerowitz E, Zafar A, Drobni ZD, Bolster MB, Kohler M, D'Silva KM, Dau J, Lockwood MM, Cubbison C, Weber BN, Mansour MK; BACC Bay Tocilizumab Trial Investigators. Efficacy of tocilizumab in patients hospitalized with Covid19. N Engl J Med. 2020;383(24):2333-2344.

\section{Publisher's Note}

Springer Nature remains neutral with regard to jurisdictional claims in published maps and institutional affiliations. 